By WILLIAM H. CARLSON

\title{
Library Planning for the Postwar World
}

Mr. Carlson, librarian, University of Arizona, read this paper at the meeting of the Junior College Libraries Section, June 25,1942 .

$\mathrm{E}^{\mathrm{n}}$ ERY ENTERPRISE of any consequence must seek its objectives through some kind of a plan, no matter how imperfectly realized or how poorly conceived. It has always been so, but more and more, in the modern world, deliberate, carefully formulated, long-range planning has been receiving increasing attention, as is witnessed by a succession of five-year and other wellpublicized planning efforts. It has been characteristic of much of this recent planning that it has had its genesis in social crisis and ferment. Thus in our country the depression brought the National Resources Planning Board as the chief planning agency of our Federal government and, as a nongovernment effort, organization of the National Economic and Social Planning Association, recently reorganized, strengthened, and renamed the National Planning Association. Both of these organizations have made commendable and stimulating contribution to the literature of planning and increasingly and independently men of vision and goodwill are giving their best thought and effort to molding an improved and desirable design for the world of the future.

Much of our planning in America has been sporadic, haphazard, lacking in integration and a complete over-all view embracing all facets of our national life, cultural, religious, economic. It remained for the war, with the Axis powers springing to the execution of long-nourished and carefully matured plans for world conquest, to bring home to the democracies with terrible urgency the need for a complete, coordinated planning of the war effort. As these lines are written our outstanding leaders and best brains are in conference in Washington, London, Moscow, Melbourne, Chungking, planning increased production and complete integrated military effort and mobilization of every aspect of life for the majority of the world's population. One aspect of this race to catch up with and frustrate the planners of the Axis powers that is perhaps new, and certainly of good omen, is that even in this period of urgency and all-out war effort men are giving detailed attention to the kind of a place the postwar world will be. More and more they are thinking and saying, "If this is the way to get cannon it is also the way to get the good things of life."

It is to the good things of life that the Postwar Planning Committee of the American Library Association hopes to make some constructive contribution. The committee was created by action of the Executive Board of the A.L.A. on June 25, 
1941, appointments were made in August, and the first meeting at which all members were present was held at A.L.A. Headquarters, October I6-I7. All phases of library activity, the library schools, public libraries, school libraries, and college and university libraries are represented on the personnel of the committee, which also includes a wide geographic distribution.

At the first committee meeting the chairman, Dr. Joeckel, presented a preliminary plan, prepared by himself, for an attack upon the problem of library service in the postwar period. This tentative draft, which in its major points was approved by the committee, indicated the chief subdivisions in the library field for which planning is necessary as: I. Public libraries, 2. School libraries, 3. Libraries in higher education, 4. Library cooperation, particularly among research libraries. It was agreed unanimously by the committee that the public library subdivision should be given priority of treatment and development.

\section{Preliminary Plan}

The projected plan for such treatment provided four stages of development:

I. An inventory of existing library service and resources in all sections of the country by states, counties, and minor civil divisions, indicating areas completely without service and the general level of service in areas now having public libraries.

2. Comparison of existing services with recognized standards in American library service.

3. Detailed study of areas with and without public library service, including special attention to economic ability, educational levels, sparsity or density of population, and existing types of library service units.

4. Formulation of a detailed plan for national public library service based on the facts brought out by the analysis and study indicated in the first three steps.

It was envisioned that the plan formulated in step four would need to include the following major points:

I. Patterns for organization of library service, including definite recommendations as to the kinds of library units suitable in different regions and areas. This would include special consideration of rural library service, with particular attention to those areas containing one third of the total population of the country, now entirely without public library service, as well as those areas with nominal, though inadequate, service, estimated to contain an additional one third of the entire population.

2. Essential facts regarding support and ability to support library service in various localities and sections of the country.

3. A study of the library personnel situation nationally, including present number of professional and clerical staff members, with a forecast of personnel requirements which would be of special value to governmental agencies and those educational institutions which have assumed responsibility for professional library education.

4. Relationship of the public library to school libraries, especially in rural areas, and the place of the public library in adult education.

5. Study of the present physical plant of public libraries with an accurate estimate of the national needs for library housing and equipment.

6. Intergovernmental and interlibrary relationships, including relations of Federal libraries and their service to state and local libraries, contracts for library service between units of local government, state-local relations, and the role of the state library agency in the planning and organization of library service.

\section{Six-Month Study}

It will be recognized at once that a comprehensive analysis and study of this kind will require more time, effort, and 
continuous application than any committee can give it, more too than any existing agency of the A.L.A. could devote to it. For this reason the committee projected a modest budget, but with salaries which would attract the best brains in our profession, for a full-time, careful, analytical six-month study of the entire public library situation.

The proposed study and plan was submitted to various foundations and Federal agencies with heartening evidences of interest. While funds for the complete and exhaustive study have not yet been secured, the Federal government has, through its National Resources Planning Board, provided funds for a meeting of minds to consider and restate the present standards for public library service.

These funds made possible a meeting of the committee, held in Chicago, May 7-9, with twenty-three consultants on various phases of public library service and several representatives of the A.L.A. in attendance. The various consultants had in advance been asked to give detailed attention to present standards in specific sections of the public library field and to formulate a restatement of them. These preliminary reformulations were organized and reworked by the committee chairman into a document which served as the basis for discussion and study by the assembled group. Three days of intensive effort and thought were devoted to this document by all the librarians present, with subcommittees considering various phases of library service. The document emerged from this careful, cooperative study considerably altered and constituting, in the opinion of the writer, an excellent statement of the conditions which must be met by localities, states, and the Federal gov- ernment for adequate and efficient public library service. As they have now been restated by the committee the standards contain much that follows previous statements of standards, but there are some new concepts and elements introduced and perhaps the entire statement is characterized by a comprehensiveness, a freshness of viewpoint, and an urgency and seriousness of purpose not present in previous standards.

\section{Comparison of Standards}

Actually the proposed standards, which were given final consideration and approval at the Milwaukee Conference, represent, in the main, the second step proposed by the committee in its first Chicago meeting, with some projection, by inference and direct statement, of the fourth step, the final formulation of a plan. It should be emphasized, however, that basically the work of the committee and its consultants has not yet reached the definitive planning stage. It is still hoped that funds will be found to finance the detailed survey of existing library services and needs, originally projected as the first and essential step in preparing a complete library plan. If such a detailed study can be made, it should serve as the basis for a complete, thorough, and intelligent public library plan for the nation, squarely and firmly based on realities.

College librarians will note, and should be expected to note, that so far the committee has given little attention to those library problems peculiar to colleges and universities. This does not mean that it is believed that these libraries will be of less importance in the postwar world but only that their problems are not as urgent or do not affect as many people as do those of 
the public libraries. Ultimately, of course, a complete national library plan will include college and university libraries, the large research libraries, and special libraries in which lie a substantial part of the present and future cultural wealth and strength of our country. It is the intention of our committee to work closely with the National Resources Planning Board and to evolve, while the war races on, a plan for all phases of library service which can be neatly fitted in as a small but important part of the master plan which the board is striving to perfect for the total national life.

\section{Applicable to School and College Libraries}

The more comprehensive, intelligent, and capable of realization that our plans for postwar library service can be the less will be the strain and difficulties for librarians and public alike, of the inevitable, difficult, and complex postwar readjustments. Much that emerges from the projected careful study of the public library situation will be applicable to the college and school libraries. With the public library problems well understood and on their way to successful solution, the place of school, college, university, and research libraries can much more readily be integrated into the national library mosaic, a mosaic that everyone will agree should have more unity of organization, more strength of outline, more harmony and balance, than the present situation, with its brilliant highlights, its confused and overlapping sectors, and its great voids.

We must all realize that it is one thing to make a plan, pretty on paper and sound in principle, and quite another thing to translate it into reality. When the war is won there will be the inevitable psychological letdown. Old doubts, old divisions, old political cleavages, outmoded social and economic customs, and plain ordinary human selfishness and cussedness, now submerged in the grave necessities of the moment, will rise to reassert themselves. This will be a time of challenge, lacking the dramatic compulsions of the war effort, but which will permit no relaxation on the part of our library leadership. It is to be hoped that an adequate, intelligent, and realizable blueprint of the place of libraries and librarianship in the better postwar world we all mean to have will be ready to mitigate the difficulties and point the way to the important part libraries will need to take in that world.

\section{Real Testing Time}

In the opinion of the writer it will be the ten or fifteen years following the war that will be the real testing time for America and the United Nations, even more, and this is said advisedly, than the war years. In every major war people have cried out that it must not happen again but it always has and frequently surprisingly soon, as our generation is tragically and cruelly learning. In the past, wars have seemed to strain or exhaust the moral fiber of peoples, with resulting periods of corruptness, laxness, and graft, as indicated by the post-Civil War and First World War periods. If we are to avoid a similar period of wearily drifting on our oars and rapidly losing gains achieved at fantastic human and material costs we will have to be, as a nation and as a profession, both stronger and more intelligent than our forebears have been.

Now we are saying, over and over 
again, that we are struggling to preserve our way of life. The present upheaval is so tremendous that we can never return to our old way of life. However, we may now reasonably expect eventual military success which will assure us the opportunity, if we have the will and strength left to grasp it firmly and determinedly, of not having an alien way of life imposed on us by our enemies. In our new, postwar way of life we must strive to retain the best of the old, just as in our restated library standards we retain the best of the old.

It is possible that in the postwar world the function of the library will be visualized in different terms than it has been. One thing that may change, that in fact always changes in periods of grave national crisis, and which may become permanent, is the abandonment of the old professional ideal of strict neutrality and impartiality, of not taking sides or pleading a cause, even that of our own form of government. The library of the hoped-for free world of tomorrow may very definitely and consciously take its place, permanently and not just for the duration of some period of actual crisis and struggle for survival, on the side of democracy and freedom.

\section{Policy Not Paradoxical}

Fundamentally, such a policy for libraries in a free world need not be paradoxical. The library can still secure and make available the writings of other philosophies and other ways of life. Now that we stand at the brink of disaster, belatedly and desperately striving to snatch our freedoms back and create a world where all men can continue to enjoy them, many of us may agree that libraries of the future should dynamically, actively, and continuously strive for a world and a national spirit that will be inhospitable to those philosophies which consciously seek to destroy human liberties. The whole program of library service in such a world can then be directed toward an understanding and appreciation of the free way of life and the enlightenment of a citizenry which will not only live intelligently but will fully appreciate the worth and significance of the freedoms it enjoys.

If such a change does come a very considerable increase in responsibility will be placed on librarians in comparison with the traditional policy and ideal of strict neutrality and impartiality. If in the words of the Librarian of Congress, librarians "must become ... the affirmative and advocating profession of the attorney for a cause," they must clearly realize the dangers in such a policy. From the positive, zealous pleading of a cause it is only a short step to the negative, zealous, and fanatic suppression of all that seems to be opposed to that cause or any cause which does not seem comfortable and convenient. When and if we reach that stage we will have come to the very thing we are fighting against, a burning of the books, whether we actually burn Mein Kampf in the public squares or not.

\section{Reading in Planning Field}

It is believed that all librarians will find some reading in the planning field enlightening and encouraging. As a good introduction the volume by Galloway and others, Planning for America, published by Holt in $194 \mathrm{I}$, is recommended. This is a book which should be in every college library. For its stimulating visions of what can be in the postwar world, the little Personal Growth Leaflet number 15I, 
After War Educational Reconstruction, published by the National Education Association, is suggested. Copies of this little statement, costing only one cent each, might be distributed free by college and university libraries. Three encouraging and popular pamphlets by the National Resources Planning Board, which should be read, are After Defense -What?, After the War-Full Employment, and Better Cities. Henry M. Wriston's Prepare for Peace is also of value because of the common-sense and realistic way in which it faces the political, economic, and human difficulties that will rise to plague the United Nations once the compelling bonds of making war on a common enemy fall away.

That the reconstruction period, some writers to the contrary, will be difficult in the extreme, seems inescapable. There is some ground for believing, however, that we may be wiser and luckier than men have yet been. Included in this evidence is the detailed attention people in all walks of life are giving to the kind of a place the world will be when men again fly on errands of goodwill instead of hate and misery. If we, as librarians, have fortitude, courage, and wisdom we can play an important part in making the world, through enlightenment, a really better place.
Anyone reading in the literature of planning will be struck by the recurring emphasis, on the part of educators, economists, industrialists, and journalists, for the need of a moral and spiritual resurgence in the postwar world, often voiced with almost Messianic fervor. The frequency and apparent sincerity with which this thought is voiced indicates that it may be more than the customary human weakness of seeking aid and comfort in a period of danger from a higher power. The writer believes that here lies the nub and the best promise for an improved world after Hitler and Hirohito have been put in their places. As an excellent example of this stirring call for a moral rebirth, it seems fitting to conclude this brief paper with the following statement by President Levering Tyson of Muhlenberg College in an address to his student body last fall.

We need a moral and spiritual crusade to bring back sanity once more, fundamental honesty in our dealings with one another, right and justice in our private and public life, humility and gentleness-and gentlemanliness-in our behavior, truth and softness in our speech, clarity of eye and purpose, decency in our literature, the abandonment of brutish manners, simplicity of existence, the dignity of man made in the image of his Master. We need desperately to be afraid of that cowardice which induces a failure to recognize the real issue between just plain right and just ordinary wrong. 